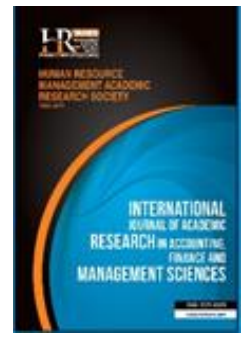

International Journal of Academic Research in Accounting, Finance and Management Sciences

Vol. 8, No.4, October 2018, pp. 120-130

E-ISSN: 2225-8329, P-ISSN: 2308-0337

(C) 2018 HRMARS

www.hrmars.com

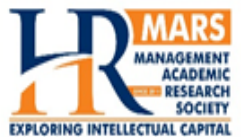

To cite this article: Muthoka, N. I., Oluoch, O., Muiruri, P. M. (2018). The Influence of Branchless Financial Innovation on Market Capitalization of Commercial Banks Listed in NSE, Kenya, International Journal of Academic Research in Accounting, Finance and Management Sciences 8 (4): 120-130.

\title{
The Influence of Branchless Financial Innovation on Market Capitalization of Commercial Banks Listed in NSE, Kenya
}

\author{
Nicodemus Itivi Muthoka ${ }^{1}$, Oluoch Oluoch ${ }^{2}$, Paul Munene Muiruri ${ }^{3}$ \\ 1,2Department of Business Administration, Jomo Kenyatta University of Agriculture and Technology, \\ ${ }^{1}$ E-mail: nicodemusmuthoka@gmail.com (Corresponding author) \\ ${ }^{3}$ Department of Business Administration, Management University of Africa, Kenya
}

\begin{abstract}
The study sought to evaluate the impact of Branchless financial innovation on Market capitalization of listed Commercial Banks in Kenya. Financial sector in Kenya has experienced a noteworthy change over the most recent years. Numerous new increasingly proficient and constant financial processes and products have come into place. In spite of the unquestionable significance in innovation, its impact on investor value isn't constantly clear since there are reported instances of negative relationship between innovations and Performance. The objective of this study was to establish the impact of branchless financial innovation on market capitalization of the Kenyan listed commercial banks. The study targeted the 11 NSE listed commercial banks in Kenya as at 31st December 2017. A census survey was adopted as its sampling design. The primary data was collected from 8 key bank officials in each bank in Finance and operations departments who dealt with financial innovations. The data obtained was cleaned; coded and statistical outputs generated using SPSS version 24 statistical packages. Descriptive and inferential analysis was employed to analyze the data where Pearson's and regression analysis were used. The findings revealed that Branchless banking innovation had a statistically significant effect on the market capitalization of the listed commercial banks in Kenya. Based on the findings of the study, it can be concluded that Branchless banking financial innovation influence market capitalization of listed commercial banks in Kenya strongly and positively. It is therefore recommended that policy makers of commercial banks who are mainly the Government and the management, to embrace Branchless banking financial innovation and encourage customers to use them. This study did not exhaust all financial innovations as the branchless banking only accounted for $54.3 \%$ and therefore, a further study is recommended to include other financial that account for the remaining $45.7 \%$ and again a comparative study should be done using secondary data as this study focused on primary data.
\end{abstract}

Key words

Branchless banking, market capitalization, Nairobi Security Exchange, financial innovation

Received: 09 lan $2019 \quad$ (C) The Authors 2018

Revised: 09 Feb 2019 Published by Human Resource Management Academic Research Society (www.hrmars.com)

Accepted: 15 Feb 2019 This article is published under the Creative Commons Attribution (CC BY 4.0) license. Anyone may reproduce, distribute, translate and create derivative works of this article (for both commercial and noncommercial purposes), subject to full attribution to the original publication and authors. The full terms of this license may be seen at: http://creativecommons.org/licences/by/4.0/legalcode

\section{Introduction}

Branchless banking financial innovation has been defined to be the process of performing banking transactions through a mobile device such as a mobile phone or Personal Digital Assistant (Boston Consulting Group, 2009). Financial innovation has been defined to be technological innovations which has a big influence on the pricing model, in the market share, in the company's revenue (OECD, 2011) while Nofie (2011) defines innovation as the entrance of a completely new and better produce and/or a method that lowers the price of executing existing financial services. In the finance industry, innovation is seen as the process of making and promoting new instruments, technologies, institutions and markets in the finance 
sector, which ease access to info, trading and payment means (Solans, 2003). Market capitalization evaluates a companies' and stock in exchange markets values. It is a continuous valuation in the market of a public firm whose shares are publicly traded on a stock exchange. It is calculated trough multiplying the total number of outstanding shares of the shareholders with the current market price per share at a given period of time. Computation of a market capitalization is a key part in any stock valuation formula.

Market capitalization is an essential measure for speculators in the assurance of the profits on their venture. Everyday stock value changes give openly accessible data on the wellbeing of a publicly traded organization. Market capitalization speaks on behalf of the general population on the estimation of an organization's equity. A productive security's exchange theory states that stock cost can mirror all pertinent data about an organization's recorded or present and public or private. Market capitalization can signify the measure of an organization's future money streams to its investors, principally the dividends, and the peril of getting the money streams, adequately the normal rate of return (Ologunde et al., 2008).

Financial sector in Kenya has experienced a noteworthy change over the most recent couple of years. Numerous new increasingly proficient and constant financial processes and products have come into place. In spite of the unquestionable significance in innovation, its impact on investor value isn't constantly clear since there are reported instances of negative relationship between innovations and Performance. Globally, most studies on the association of innovation and performance have been inconclusive empirically and have produced contradictory findings. Loof (2002) in a study to investigate the relationship between innovation output as the dependent variable which was measured using new sales of products per employee with five various measures of organizations performance namely: employment growth, employee sales, value added, operating profit and return on assets as the explanatory variables found out that there was a positive relationship between all the five indicators and innovation. However, this was not the case in all studies carried out as others indicated absence of a significant relationship. For instance, in a study carried out by Klomp and Van Leeuwen (2001), the findings showed that there was a positive statistically significant relationship of innovation output with sales growth; however, there was no significant relationship between innovation output and growth in employment. Again in a study by Kemp (2003) while investigating a relationship between innovation output and the growth of turnover, employment and profit, found out that there was no statistically significant linear relationship between innovation output and profit.

The Kenyan financial sector has experienced huge changes over the recent two decades. A ton of changes have been attempted in the sector that have prompted multiplication of financial products/items, activities and organizational structures that have enhanced and expanded the proficiency of the financial framework. Advances in innovation and changing financial conditions have made force for this change. All these improvements combined with changes in the global financial sector and the expanding mix of domestic and worldwide financial markets have prompted quick financial development. The rising significance of the financial sector in present day economies, just as the quick rate of advancement in that sector, has created a study enthusiasm for financial innovation (CBK, 2013). It is on this ground that this research was carried out.

\subsection{Statement of the Problem}

In spite of the numerous financial innovations which is a key pillar that has been upheld by CBK, a portion of the Kenyan banks have kept on encountering a decline in market value (Bank supervision, 2015). Innovation is broadly viewed as a standout amongst the most imperative wellsprings of feasible upper hand in an inexorably evolving environment, since it prompts product and process improvements, makes continuous advances that causes firms to endure, enables firms to develop all the more rapidly, be progressively productive, and at last be more gainful than non-investors (Murat et al., 2013). Overall, there has been colossal strategic innovation moves in the banking industry.

Innovation is a standout amongst the most essential factors in the development of new items and one of the fundamental drivers for economic growth (Peilei, 2011). In spite of enormous achievement in Kenya's Banking sector advancements over the most recent 10 years, an investigation of the monetary condition shows that the overall economic development acknowledged throughout the most recent 10 years' extents between 3-6\% which is to a great extent underneath the Government target scope of 6-8\%. In addition, the sector has seen 3 banks crumple which came about due to low buyer trust in the area and 
generally the strength of the sector. This crumbled further after the presentation of the interest rate cap in August 2016, which is relied upon to bring down interest margins and result in slower credit development. Non-performing credits have likewise expanded over the part from an industry average of $5.2 \%$ before 2015 to an average of $7.9 \%$ as at September 2016, predominantly ascribed to a challenging business environment and upgraded supervision by the Central Bank. Thusly, banking sector valuations have gone down essentially, with industry P/B declining from 1.9 occasions as at the end of 2014 to 0.8 occasions as at the end of January 2017 (Kenya Banking Sector, 2017).

Hjalager (2010) claims that more research is needed to evaluate the potential differentiated effect of innovation types on Market Capitalization. According to Choonho et al. (2014), different types of innovation strategy have been introduced in innovation studies, however, their effect on firms' Market Capitalization have been underexplored. A few of studies like Murat et al., (2013) and Chooncho et al., (2014) have been conducted to identify the effect of innovations on Market value.

Bonn (2000) argued that most of the studies in this area concentrated on effect of a few innovations on financial performance and their outcome has been empirically inconclusive and produced mixed results. For example, Scholars Pooja and Singh (2009) in their studies concluded that innovations had least impact on firm performance, while others such as Batiz-Lazo and Woldesenbet (2006) as well as Mwania and Muganda (2011) concluded that innovations had significant contribution to firm performance. Ngumi (2013) concluded that mobile phones had a higher effect on bank performance than internet services. Korir (2013) found that innovation has become an essence to provide new products and strategies to better suit different circumstances of time and market and to meet different requirements of participants in financial system.

It is at the center of such mixed conclusions that created and necessitated the need to carry out a study from a Kenyan context to establish the effects of Branchless banking financial innovations on market capitalization of listed commercial banks in Kenya.

\subsection{General Objective}

The main objective of this study was to establish the effect of Branchless banking innovation on market capitalization of listed commercial banks in Kenya.

\subsection{Research Hypotheses}

This study sought to address the following pertinent research hypotheses;

$\mathrm{HO}_{1}$ : Branchless banking innovation has no significant effect on the market capitalization of listed commercial banks in Kenya.

\section{Literature review}

This section reviews both theoretical and empirical literature that hypothesizes the influence of Branchless banking innovation and Market capitalization.

\subsection{Transaction Cost Innovation Theory}

The theory was put forward by Niehans (2006). He argued that decline in transaction costs is the governing principle of financial innovation. Furthermore, financial innovation results in technology improvement leading to transaction costs reduction. Financial innovation can be accelerated by transaction costs reduction and financial service improvement. He further contended that transaction costs are reduced by financial innovation hence increase in firm's financial performance. This theory is relevant for this study because the use of financial innovations such as mobile banking and electronic banking that are some of the independent variables for this study can substantially reduce a firm's transaction costs hence improving the firm performance measure like market capitalization. Furthermore, use of IT related innovations provides efficient management and coordination of the firm. IT related financial innovations provides off -site access to the organizations internal database and other relevant sources of information hence reduction in the transaction costs. Financial innovations such as agency, internet and mobile banking as a result can reduce operations costs hence influencing capitalization for the bank. 
Hicks and Niehans (1983) proposed this theory when they studied innovation. Reduction of transaction costs is what they considered as the underlying principle of financial innovation feedback which was a result of technology improvement. Financial innovations and financial services advancement can be triggered by the decline in transaction cost. Microscopic economic structure change was the perspective under which financial innovation was studied. Reduction of the costs of transaction was the main motive behind financial innovation. Another perspective of explaining this theory was the financial innovation radical motive which reasoned that the reason for financial innovations was for the firm to earn profits and benefits.

\subsection{Empirical Review}

According to Kato et al., (2014) mobile banking is the use of mobile phones to deliver banking services. In delivering banking services through embracing mobile technology to conform to improvement of technology in the banking sector, banks have recently gone through major technological changes. In delivering accessibility and efficiency of banking services to customers with absence of obstacles of time and location, this banking model becomes very useful.

The foundation of the banking industry is swayed by the speedy development and growth of information technology. Service bundling, process integration, monopolization of extensive branch network and scale economy strategies have recently been the areas studied in baking industry (Fang, 2009). However, this basic theory of combined model is questioned by the advancement of mobile and related technology. According to Wang et al., (2006), the increased in number of customers using devices such as mobile has been due to the growth of wireless technology. Fjermestad et al., (2006) indicated that the ever-changing new technology is changing resulting to new approaches in many areas of business.

A study Malhotra and Singh (2009), on effect of internet banking on risk and financial performance determined that banks utilizing internet banking are likely to be large, more efficient in operations and will get more profits, meaning improved financial performance. They further contented that that banks that have adopted internet banking are likely to have much better and quality asset and are well managed to reduce the expenses for equipment and construction. On the other hand, they concluded that smaller banks that have adopted internet banking are likely to result in decline in profitability meaning decrease in financial performance.

Johnstone (2010) argued banks can distinguish their delivery of banking service by use of mobile banking that is developing gradually. By use of mobile banking applicators and devices for users, banks and other financial institutions have a favorable condition to generate profits, control cots, generate new business, retain market share and attract customers.

\section{Methodology of research}

\subsection{Research Design}

This study used descriptive research design and Panel quantitative research design to describe the influence of various financial innovations on market capitalization of listed commercial banks in Kenya. Kothari (2004) defines descriptive survey model as a plan which pursues and identifies precisely the attributes for a person, circumstance or a category. Therefore, this perspective was suitable for this study, since the study collected in-depth information through descriptions and is useful for singling out variables. Descriptive research has the benefit that the subject is noted in a completely natural and unaltered natural environment and that it permits respondents to reply in their time frame (Cooper and Schindler, 2014).

\subsection{Target Population}

This study population was composed of all the 112 senior managers in Finance departments in the 11 listed commercial banks at the NSE. According to CBK, there were 11 listed commercial banks at the NSE as at $31^{\text {st }}$ December 2016. The choice for the listed banks was made because data on the dependent variable market capitalization is readily available at NSE and CBK annual reports and therefore the ease in determining the relationship between Branchless banking financial innovations on Market capitalization. The main reason for choosing these employees from finance and operations departments was because 
they are responsible for financial innovation in the bank and have a firsthand knowledge on the link between financial innovation and market capitalization.

\subsection{Respondents Sample Size determination}

This study targeted the 11-Senior financial and operations managers from all the listed banks in Kenya. Therefore, to determine the respondent's sample size, Yamane's (1967) formula as cited below was adopted.

$$
\mathrm{n}=\mathrm{N} /\left(1+\mathrm{Ne}^{2}\right)
$$

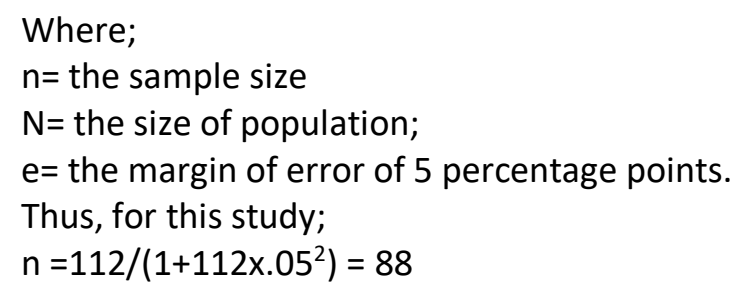

\subsection{Data Collection Instruments}

Data collection was done from both primary and secondary sources. Instruments used in this study included a questionnaire and financial statements available at NSE and CBK quarterly reports.

\subsection{Data Analysis and Presentation}

After data was obtained, it was subjected to a factor analysis using principal axis factoring and orthogonal varimax rotation. This analysis was used to cluster together similar variables and obtain lesser dimensions that mirrored the relationships or associations among these inter-related factors or variables. The factors were identified using an eigenvalue cut-off of 1.0. From this, items that met a minimum criterion of having a primary factor loading of 0.5 or above were chosen to belong to a specific factor. The factors were then tested for reliability using factor analysis. Descriptive statistics such as measures of central tendency and measures of dispersion were used to summarize the data. In addition, to test the statistical significance the independent variable (branchless banking) on the dependent variable (Market Capitalization of the Bank), simple linear regression analysis was used while Pearson's regression was used to demonstrate the strength of the linear relationship.

The general linear regression equation defined and tested is provided in the equation below:

$M C_{i}=\beta 0+\beta_{1} B_{i}+\varepsilon$

Where:

$M C_{i}=$ Market Capitalization of Bank $\mathrm{i}$

$\beta_{0}$ is a constant term

$\left(\beta_{1}\right)=$ Regression coefficients value

$\varepsilon_{\mathrm{i}}=$ Error term

$\mathrm{BB}_{\mathrm{i}}=$ Branchless banking of banks $i$.

\subsection{Diagnostic tests}

Executing diagnostic examinations on the data permits the researcher to identify the most suitable technique. The study tested for normality where a normal Q-Q plot was used. Other diagnostic tests used were Multicollinearity which was tested using Variance inflation factor and finally homoscedasticity which was tested using a scatter plot between residuals and predicted values.

\section{Results and Discussions}

\section{1 . Factor analysis}

Factor analysis was conducted in the study for the response and explanatory factors in order to reduce the constructs in each section if need be. The factors were identified using an eigenvalue cut-off of 
1.0. From this, items that met a minimum criterion of having a primary factor loading of 0.5 or above were chosen to belong to a specific factor.

Table 1. Results of exploratory factor analysis

\begin{tabular}{lccc}
\hline \multicolumn{1}{c}{ Factor and item description } & $\begin{array}{c}\text { Factor } \\
\text { loading }\end{array}$ & $\begin{array}{c}\text { Initial Eigen } \\
\text { value }\end{array}$ & $\begin{array}{c}\text { \% variance } \\
\text { Explained }\end{array}$ \\
\hline $\begin{array}{l}\text { Market Capitalization } \\
\text { The bank has a good improvement on the market value/stakeholders' }\end{array}$ & .830 & $\mathbf{2 . 3 4 1}$ & $\mathbf{2 1 . 2 8 2}$ \\
value over the last 5 years & .509 & \\
$\begin{array}{l}\text { The number of existing shares for the bank have increased over the last } \\
5 \text { years }\end{array}$ & & .774 \\
$\begin{array}{l}\text { The bank has a better shareholders value than industry average } \\
\text { (Benchmarks) }\end{array}$ & .913 & \\
$\begin{array}{l}\text { Agency banking has increased the market share of the bank over the } \\
\text { last 10 years }\end{array}$ & & $\mathbf{4 . 4 5 4}$ & $\mathbf{7 4 . 2 3 2}$ \\
\hline $\begin{array}{l}\text { Mobile Banking } \\
\text { The bank has instituted mobile banking for and value of loans issued } \\
\text { through }\end{array}$ & .205 & \\
$\begin{array}{l}\text { Mobile banking has increased market value of the bank for the last } 5 \\
\text { years }\end{array}$ & .896 & \\
$\begin{array}{l}\text { The number of the mobile banking transactions have increased over } \\
\text { time }\end{array}$ & .918 & \\
$\begin{array}{l}\text { The volume of mobile banking transactions has increased over time } \\
\text { The number of customers using mobile banking platform for the bank } \\
\text { have increased in the last } 5 \text { years }\end{array}$ & .841 & .784 \\
\hline $\begin{array}{l}\text { Mobile banking transactions has increased the market share of the bank } \\
\text { over the last } 10 \text { years }\end{array}$ & .642 & \\
\hline
\end{tabular}

The results showed that all the factor loadings were found to be above 0.5. Therefore, all the items were accepted based on the general rule of thumb for acceptable factor loading of 0.50 and above. No item was removed or dropped. All the variables had factor loadings above $50 \%$ and were acceptable based on the general rule as no item was removed.

\subsection{Reliability test}

A reliability test was the performed using Cronbach's Alpha to see if the identified factors or constructs were reliable and the results were presented in table 2.

Table 2. Reliability test

\begin{tabular}{lccc}
\hline \multicolumn{1}{c}{ Factor } & Number of constructs & Cronbach Alpha & Remarks \\
\hline Market Capitalization & 3 & 0.738 & Acceptable \\
Mobile Banking & 6 & 0.885 & Acceptable \\
\hline
\end{tabular}

The results indicated that Market capitalization had a reliability coefficient of 0.738 , while branchless banking had a coefficient of 0.885 . According to Mugenda and Mugenda (2003), a coefficient of 0.70 and above implies high degree of reliability of the data. All the proposed constructs were found to be reliable.

\subsection{Descriptive Analysis}

The respondents were asked to respond to the effect of Mobile Banking on Market Capitalization of listed Commercial Banks in Kenya in Table 3. The results in Table 3 indicated that majority of the respondents agreed that the bank had instituted mobile for and the value of loans issued through, this was indicated by a mean of 4.07 and a standard deviation of 0.682 . $23.3 \%$ strongly agreed while $64.0 \%$ agreed. A corroborating research by Johnstone (2010) argued that mobile banking has evolved and is still evolving as the new front on which banks can differentiate their service delivery. Again a study by Misati et al. (2010), argued that mobile banking had grown a range of services that a bank could offer increasing incomes for banks. 
Table 3. Effect of Mobile Banking on Market Capitalization of listed Commercial Banks in Kenya

\begin{tabular}{|c|c|c|c|c|c|c|c|}
\hline Mobile Banking & 1 & 2 & 3 & 4 & 5 & Mean & SD \\
\hline $\begin{array}{l}\text { The bank has instituted mobile banking for and the value of the loans } \\
\text { issued through }\end{array}$ & 0.0 & 3.5 & 9.3 & 64.0 & 23.3 & 4.07 & .682 \\
\hline $\begin{array}{l}\text { Mobile banking have increased market value of the bank for the } 5 \\
\text { years }\end{array}$ & 0.0 & 4.5 & 2.3 & 81.8 & 11.4 & 4.00 & .567 \\
\hline The number of mobile transactions have increased over times & 0.0 & 4.5 & 8.0 & 64.8 & 22.7 & 4.06 & 701 \\
\hline The volume of mobile transactions have increased over time & 0.0 & 6.8 & 4.5 & 54.5 & 34.1 & 4.16 & .801 \\
\hline $\begin{array}{l}\text { The number of customers using mobile banking transform for the } \\
\text { banking platform for the bank have increased over } 5 \text { years }\end{array}$ & 0.0 & 0.0 & 10.2 & 67.0 & 22.7 & 4.13 & .563 \\
\hline $\begin{array}{l}\text { Mobile banking transactions has increased the market share of the } \\
\text { bank over the last } 5 \text { years }\end{array}$ & 0.0 & 4.5 & 10.2 & 55.7 & 29.5 & 4.10 & .759 \\
\hline
\end{tabular}

On whether mobile banking had increased market value of the bank have increased market value of the bank for the 5 years, the respondents agreed as indicated by a mean value of 4.00 and a standard deviation of $0.567 .81 .8 \%$ agreed and $11.4 \%$ strongly agreed. The respondents on average agreed that the number of transactions had increased over time as revealed by a mean of 4.06 and a standard deviation of $0.701 .22 .7 \%$ of the respondents strongly agreed while $64.8 \%$ of the respondents agreed. The respondents again agreed that the volume of mobile transactions had increased over time as indicated by a mean of 4.16 and a standard deviation of $0.801 .34 .1 \%$ strongly agreed, $54.5 \%$ agreed, $4.5 \%$ were undecided whereas none of them either disagreed or strongly disagreed.

The results affirm to the findings reported by CBK (2013) who argued that in Kenya mobile banking has become popular among Kenyans which has brought about an increase in bank income and profitability. By the end of the year 2012 transactions in mobile banking rose to more than 52 Million and were worth more than 138 billion Kenya shillings all the way from a total of 17 million dealings worth approximately 40 billion shillings in Kenyan currency by July 2009. Ngumi (2013), in a study to examine the influence of bank's financial innovations on the performance of Kenyan banks found out that mobile banking has penetrated highly in the country. This was taken to be the ability to offer an alternative channel for a bank's service delivery. The simplified way with which the users (customers) can use mobile phones to make transactions has popularized mobile banking to not only users or customers but also to the banks. Banks have been able to build partnerships with providers in mobile telephony industry increasing the type and number of transactions/dealings that banks and customers can conduct on the mobile phone and thus creating more opportunities for income generation for banks.

The study also showed that majority of the respondents, $67.0 \%$, agreed that the number of customers using mobile banking platform for the banking platform for the bank have increased over 5 years. $22.7 \%$ strongly agreed, $10.2 \%$ were undecided. On average the respondents agreed as indicated by a mean of 4.13 and a standard deviation of 0.563 . The findings were affirmed by a study carried out by Malhotra and Singh (2009) whom in a study "impact of banking innovations on bank performance and risk" found out that on average mobile and internet banks are bigger, makes more profit and have efficient and better operations. It was also found that internet and mobile banks have a bigger asset quality and managed at minimal expenses in building and required resources.

Finally, the respondents agreed that mobile banking has increased the market share of the bank over the last 5 years as indicated by a mean of 4.10 and a standard deviation of $0.759 .54 .7 \%$ agreed and $29.5 \%$ strongly agreed. These findings corroborate with a research by Tchouassi (2012). The study found that most banks have adopted mobile banking applications allowing customers to conveniently do their banking using their mobile devices anytime and anywhere. Many Kenyans have adopted it due to its convenience in transactions making it popular. This has as a result brought about profitability and has increased profitability of the bank.

\subsection{Diagnostic tests}

The study tested for normality where a normal Q-Q plot was used. Other diagnostic tests used were Multicollinearity which was tested using Variance inflation factor and finally homoscedasticity which was tested using a scatter plot between residuals and predicted values. The data was found to meet all the 
assumptions and hence the parametric tests such as linear regression and Pearson's correlation would be performed.

\subsection{Regression analysis}

A simple linear regression analysis was performed with Mobile Banking Innovation as the predictor variable and market capitalization as the dependent or response variable to assess the effect of mobile banking on market capitalization of listed commercial banks in Kenya. To achieve this, the following hypothesis was tested.

$\mathrm{HO}_{1}$ : Mobile banking has no significant effect on market capitalization of listed commercial banks in Kenya

The results were presented in the following Tables 4, 5, and 6.

Table 4 showed the coefficient of determination which indicated the percentage variation in the dependent variable that is explained by the independent variable. In this section, Mobile Banking was found to explain $54.3 \%$ of the variation in Market capitalization as indicated by a coefficient of determination $\left(R^{2}\right)$ value of 0.543 .

Table 4. Model Summary for the simple regression analysis of Mobile banking

\begin{tabular}{ccccc}
\hline Model & $\mathrm{R}$ & $\mathrm{R}$ Square & Adjusted R Square & Std. Error of the Estimate \\
\hline 1 & $.741^{\mathrm{a}}$ & .549 & .543 & .21815 \\
\hline
\end{tabular}

a. Predictors: (Constant), Mobile Banking

Table 6 shows an ANOVA table which determined the significance of the model. The results indicated that the model with Mobile banking as predictor variable significantly predicted Market capitalization ( $F=$ 104.506; $p=<0.0001$ ).

Table 6. ANOVA for the simple regression analysis of Mobile banking

\begin{tabular}{clccccc}
\hline & Model & Sum of Squares & $\mathrm{df}$ & Mean Square & $\mathrm{F}$ & Sig. \\
\hline \multirow{2}{*}{1} & Regression & 4.973 & 1 & 4.973 & 104.506 & $.000^{\mathrm{b}}$ \\
& Residual & 4.093 & 86 & .048 & & \\
& Total & 9.066 & 87 & & & \\
\hline
\end{tabular}

a. Dependent Variable: Market Capitalization

b. Predictors: (Constant), Mobile Banking

Table 7 then showed the model coefficients.

Table 7. Model Coefficients for the simple regression analysis of Mobile banking

\begin{tabular}{|c|c|c|c|c|c|c|}
\hline \multirow[t]{2}{*}{ Model } & & \multicolumn{2}{|c|}{ Unstandardized Coefficients } & \multirow{2}{*}{$\begin{array}{c}\text { Standardized } \\
\text { Coefficients } \\
\text { Beta }\end{array}$} & \multirow{2}{*}{$\mathrm{t}$} & \multirow{2}{*}{ Sig. } \\
\hline & & B & Std. Error & & & \\
\hline \multirow{2}{*}{1} & (Constant) & 1.067 & .330 & & 3.236 & .002 \\
\hline & Mobile Banking & .782 & .077 & .741 & 10.223 & .000 \\
\hline
\end{tabular}

a. Dependent Variable: Market Capitalization

From Table 7 the model equation can be written as:

$Y=1.067+0.782 X$

Where $Y$ is the Market capitalization of listed commercial banks in Kenya while $X$ is the Mobile Banking.

There is a positive and significant relationship between Mobile Banking and Market capitalization of listed commercial banks in Kenya. A unit increase in mobile Banking would lead to a 0.782 units increase in Market capitalization. Since the $P$ value was less than 0.05 at $5 \%$ level of significance, then there is enough evidence to reject the null hypothesis and conclude the alternative hypothesis which states that mobile banking has a significant effect on market capitalization of listed commercial banks in Kenya. 
These outcomes were likewise affirmed by past literature. To be exact, Mabrouk and Mamoghli (2010) completed an examination on Dynamics of Financial Innovation and Performance of Banking Firms: Context of an Emerging Banking Industry. The examination investigated the impact of the reception of two kinds of monetary developments to be specific; item innovation (mobile banking and SMS banking and so forth.) and process development (Magnetic strip card (debit, ATM and Visa card), Automatic money gadget; (Automatic teller machine; Electronic installment terminal and so forth.) on the performance of banks. The investigation included two selection practices, first mover in reception of the money related development and imitator of the primary movers. The investigation discoveries uncovered that first mover activity in item development enhances benefit while process activity positively affects productivity and proficiency. Banks that copy are less beneficial and less effective than first movers.

However, other studies failed to concur with these discoveries. An example is a study by Nader (2011) who conducted a study in Saudi Arabia in 2017 on the effect of financial innovations on the profit efficiency of banks in Saudi Arabia. The study revealed that profit efficiency of banks in Saudi Arabia was positively affected innovations such as the number of bank branches, number of ATMs and phone banking availability. However, Mobile banking, POSs and PCs were found not to improve profits of the banks.

\section{Summary and Conclusions}

The study concluded that there was a positive and strong statistically significant influence of branchless banking financial innovation on market capitalization of Kenyan commercial banks listed in the Nairobi stock exchange. This stressed on the necessity to embrace use of mobile or branchless networks for banking services. More mobile transactions are encouraged so as to increase the market value. Again more mobile users should be encouraged as it is an easier option, cheaper and convenient.

\section{Recommendations and future research}

Based on the empirical findings from the study, it is recommended that customers and banks should embrace and utilize the use of mobile and branchless networks for banking services. More mobile transactions are encouraged so as to increase the market value. Again, more mobile users should be encouraged as it is an easier option, cheaper and convenient.

This academic study has important theoretical and contextual contribution in both academics around financial innovations and banking industry managerial decision making. As discussed above different types of financial innovations indicated varying positive effect on market capitalization of commercial banks listed in NSE, Kenya. This implies that in analyzing the effect of financial innovation on market capitalization in the banking industry, each financial innovation should be treated individually and differently because of the differences in cost of each financial innovation.

Regarding academic contribution, the finding that market capitalization is positively influenced by financial innovation indicates that this type of investment can be regarded as appropriate. Due to this fact alongside the outcome that different financial innovations have varying effects on market capitalization suggests that when an in-depth evaluation is pursued by the analysts, varying kinds of financial innovations and distinct company performance measurements should be adopted.

As for managerial contribution, using market capitalization as a measure of market value allows for the examination of effect of financial innovation on performance by estimating market predictions on future profits. This method is forward looking measure of firm performance and it overcomes the backward-looking traditional method of assessing firm profitability. The use of share prices to determine the effect of financial innovation can be used by the management to determine if there is any need to proceed with a type of innovation. Furthermore, the finding that financial innovation has a positive effect on market capitalization of commercial banks listed at NSE, Kenya implies that an innovative bank is a healthy one. Therefore, any bank initiating financial innovations, regardless of whether they are internal or external, should always innovate through news release in a public relations system that ii well executed.

Further research can be carried on the comprehensive effect of differentiated effects of innovation types on market capitalization in the non-banking industry. Schumpeterian classifications method can be used to identify the differentiated effects of the various financial innovations. Furthermore, the other taxonomies would provide broader academic perspective in this area. 
Financial innovation decisions in any industry implies enormous investment as big fixed costs are involved and this makes such decisions to be considered in relation to risk as this would determine the company's profitability. Due to this fact, a further research can be carried to examine the effect of financial innovation on the risk of a company's market value.

Corporate social responsibility (CSR) is a social trend today adopted by most of the corporates. It can be interesting to do a further study and examine if CSR non-financial innovation exerts an incremental effect on firm performance. It can be worthwhile to determine if more effect on market capitalization or firm performance occurs when both CSR and financial innovations are adopted together.

\section{References}

1. Alber, N. (2011). The Effect of Banking Expansion On Profit Efficiency Of Saudi Arabia Commercial Banks. Journal of Global business and Economics, 3(1), 11-23.

2. Bátiz-Lazo, B., \& Woldesenbet, K. (2006). The dynamics of product and process innovations in UK banking. International Journal of Financial Services Management, 1(4), 400-421.

3. Bonn, I. (2000). Staying on top: characteristics of long-term survival. Journal of organizational change management, 13(1), 32-48.

4. CBK. (2013). Central Bank of Kenya. Quarterly report on Development in the Kenyan banking sector for the period ended 30th June 2013. Change and Restructuring 44 (192): 49973.

5. Central Bank of Kenya. (2013). Bank Supervision Annual Report, Kenya. Retrieved from: https://www.centralbank.go.ke/images/docs/Bank\%20Supervision\%20Reports/Annual\%20Reports/BSD201 3AnnualReport.pdf.

6. Cooper, R., \& Schindler, P. (2014). Business Research methods, Boston, McGraw- Hill lirwin $7^{\text {th }}$ edition, pp. $132-225$.

7. Fan, P. (2011). Innovation capacity and economic development: China and India. Economic change and restructuring, 44(1-2), 49-73.

8. Hicks, D., \& Niehans, J. (1983). Financial innovation, multinational banking and monetary policy. Journal of banking and Finance, 537-551.

9. Hjalager, A. M. (2010). A review of innovation research in tourism. Tourism management, 31(1), 112.

10.Johnstone, B. (2010). Mobile Banking: A catalyst for improving bank performance. Deloitte consulting.

11.Kato, G. K, Otuya, W. L, Owunza, J. D \& Nato, T.A. (2014). Mobile Banking and performance of Commercial banks in Kenya. International Journal of Current Research, Vol. 6, Issue, 12, Pp.106 70-10 6.

12.Kemp, R. G. M., Folkeringa, M., Jong, J. P. J., \& Wubben, E. F.M. (2003), Innovation and Firm performance, Journal of Management 2 (4), 12-18. Kenya Banking Sector Report (2017).

13.Klomp, N., Luuk, W., \& Van Leeuwen, G. (2001). Linking Innovation and Firm Performance: A New Approach. International Journal of the Economics of Business. 2001, Vol. 8, 3, 343-364.

14.Kombo, D.K., \& Tromp, D.L.A. (2009). Proposal and Thesis Writing: An Introduction. Paulines publications Africa, Don Bosco Printing Press, Nairobi Kenya.

15. Korir, M. C. (2014). The effect of financial innovations on the financial performance of commercial banks in Kenya. International Journal of Finance and Accounting, 1(1), 15-29.

16. Kothari, C. R. (2004). Research methodology: Methods and techniques. New Age International.

17.Lindgardt, Z., Reeves, M., Stalk, G., \& Deimler, M. S. (2009). Business model innovation. When the Game Gets Tough, Change the Game, The Boston Consulting Group, Boston, MA.

18.Loof, M., Hans, S \& Heshmati, J. (2002). Knowledge Capital and Performance Heterogeneity: A Firm-Level Innovation Study. International Journal of Production Economics. 2002, 76, pp. 61-85.

19. Malhotra, P., \& Singh, B. (2009). The Impact of Internet Banking on Bank Performance and Risk: The Indian Experience. Eurasian. Journal of Business and Economics, 43-62.

20.Murat, A., Nilgun, A., \& Fulya, S. (2013). The Relationship between Innovation and Firm Performance: An Empirical Evidence from Turkish Automotive Supplier Industry. Procedia-Social and Behavioral Sciences Volume 75, 3 April 2013, Pages 226-235.

21. Mwania, M. U. A. S. A., \& Muganda, N. (2009). An investigation on the relationship between information technology conceptualization and bank performance. Unpublished MBA Project. 
22.Nofie, I. (2011). The diffusion of electronic banking in Indonesia, Manchester Business School $O E C D, 2005$. Oslo Manual: Proposed Guidelines for Collecting and Interpreting technological Innovation Data. Paris.

23.OECD (2011), "Mixed modes of innovation", in OECD Science, Technology and Industry scoreboard 2011, OECD Publishing

24.Oh, C., Cho, Y., \& Kim, W. (2015). The effect of a firm's strategic innovation decisions on its market performance. Technology Analysis \& Strategic Management, 27(1), 39-53.

25.Ologunde, A., Elumilade, D.,\& Saolu,T.(2008). Stock market capitalization and interest rate in Nigeria: A time series analysis. International Research Journal of Finance and Economics, 4, pp. 154-67.

26.Solans, E. D. (2003). Financial innovation and monetary policy. Excerpts of speech delivered at the 38th SEACEN Governors Conference and 22nd Meeting of the SEACEN Board of Governors on" Structural Change and Growth Prospects in Asia-Challenges to Central Banking", Manila (13 February 2003).

27.Tchouassi, G. (2012). Can Mobile Phones Work to Extend Banking Services to the Unbanked? Empirical Lessons from Selected Sub-Saharan Africa Countries. International Journal of Developing Societies. Vol. 1, No. 2.

28.Wang, Y. S., Lin, H. H., \& Luarn, P. (2006). Predicting consumer intention to use mobile service. Information systems journal, 16(2), 157-179.

29.Yu, T. K., \& Fang, K. (2009). Measuring the post-adoption customer perception of mobile banking services. CyberPsychology \& Behavior, 12(1), 33-35. 